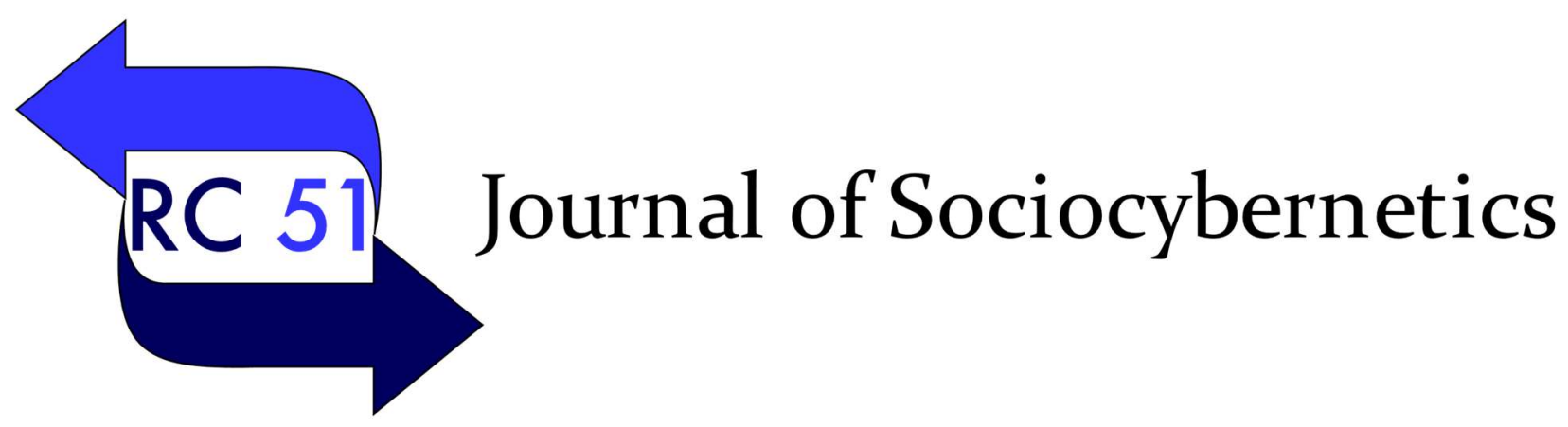

Journal of Sociocybernetics ISSN 1607-86667

ORIGINAL ARTICLE

\title{
The evolution of communication media in Moche culture
}

\author{
José Javier Blanco Rivero \\ Simon Bolívar University Venezuela
}

\begin{abstract}
The study of an ancient social system offers a good chance to survey the intricate relations between complexity and truth from an evolutionary standpoint. Assuming the improbability of the evolution of truth as a symbolic generalization that gave rise to the outdifferentiation of a functional system for science, I intend to underline the contingency of such an evolutionary pathway by studying the Moche culture. The Moche represent a suitable case study because of their elaborate and narrative-loaded pottery, which played the role of a dissemination medium along the Peruvian North Coast. Treating Andean iconography - and in general, its material culture as communication media will require us to develop the potential of Luhmann's theory of sociocultural evolution. Within this framework, I shall defend the thesis that sociocultural evolution is guided by the dynamic interaction between success and dissemination media, which, by conditioning each other, sometimes favor differentiation and gain complexity, and some others impede those possibilities. This will allow me to reach the conclusion that, although pottery played a key role in boosting social complexity in the Andean world, it did not generalized sense-making (Sinn) so as to codify communication based on the truth-value of statements with knowledge pretensions.
\end{abstract}

url:

\section{Introduction.}

The Moche (200-850 AD) populated the North Coast of Peru stretching from the Huarmey Valley in the south to the Piura Valley in the north. Known as magnificent potters, smiths, and pyramid builders (known as Huacas), they had no written language but were capable of codifying their beliefs by means of shaping mud into fine ceramics and painting on them complex narratives that described their calendar, myths, rites, and ceremonies (Donnan, 1973; Donnan \& McClelland, 1979; Quilter, 1997; Golte, 1994; Hocqueghem, 1987). Impressively realistic portrait-vessels face the observer with ancient man, probably powerful priests, shamans, rulers (Benson, 2012, pp. 86-87), and even sacrificial victims, whose blood was shed to quench the thirst of the gods (Donnan, 2001; Bourget, 2001). Exquisite jewelry made of gold, copper, and silver found on pompous tombs, such as that of the Lord of Sipán or the Priestess of San José de Moro, reveals that the characters the pottery represented were played by real people in theatrical rituals (Quilter, 2002, p. 165), accompanied by feasting and sacrifices of camelids and human victims (Uceda, 2001; Bourget, 2006; Verano, 1998). Moche iconography represents one the most challenging and interesting fields in Moche archaeology. Both fields have cooperated to throw light on each other, promising to bring Moche archaeology to almost the same level of knowledge reached by Mesoamerican archaeology. Moche 
iconographic studies can be divided between those who treat most Moche material culture as art (that is, privileging an aesthetical approach; Donnan, 1973; Donnan \& McClelland, 1979) and those who are starting to conceive it as communication media playing a major role in ritual activity and capable of representing or conveying complex narrative structures (Quilter, 1997; Golte, 1994; Hocqueghem, 1987).

If Moche material culture can be described as communication media, a whole range of research possibilities opens up for social and historical sciences - as seems to be the case within the current of communication studies, especially communication history. It is not a matter of finding new archaeological evidence to support this kind of insight, but of re-describing existent evidence in accordance with new concepts - in the present opportunity, those of a communication-based theory of sociocultural evolution.

In the field of social systems theory, Niklas Luhmann (1995, p. 114) raised to a methodological principle the improbability of the normal. As a consequence, from a functionalist perspective, what constitutes a normal social experience can be treated from the point of view of its contingency as a solution to an evolutionary problem. Because communication is the social problem par excellence, a social theory ought to start consequently from the improbability of communication, which Luhmann (1995, pp. 158-160) subdivides into three problems: (a) the improbability of understanding (that ego comprehends what alter means), (b) the improbability of dissemination or reaching (that a communication reaches more persons than those present), and (c) the improbability of success (that ego takes the selected information as a premise for its own behavior).

Problem (a) is solved by means of language, while problems (b) and (c) are the subject matter of a theory of communication media. These media suppose social systems operating with the difference between form and medial substratum, resulting in the transformation of the improbable into probable (Luhmann, 2012, p. 117). In other words, sociocultural evolution is to be understood as the mutation and expansion of opportunities for successful communication (Luhmann, 1995, p. 160). This is how sociocultural evolution is set forth.

Accordingly, if we are willing, as we are, to give insight into the intricate relations between complexity and truth, from the perspective of evolution theory by exposing the case of the Moche, the first step is to start from the improbability of the evolution and full structural development of such a medium, and second, to account for the improbability of the differentiation of a functional system for science from that very medium. By means of a communication-theoretic description of the Moche culture, I intend to demonstrate the many preconditions that an evolutionary trajectory would have to fulfill in order to reach the complexity that our actual social system has reached, as well as the dire contingency of that trajectory. The goal of this essay is not simply to explain why the Moche did not have science (and hence, did not know truth as a success medium), but to have a look at a very singular sociocultural setup spawned by social evolution and be able to learn something about it.

But how can communication and evolution theories help in understanding an ancient society, and more precisely: how to think of the problem of truth in that society? Let us take a closer look into Luhmann's social and evolutionary theory in order to answer these questions.

\section{Contributing to Luhmann's theory of sociocultural evolution}

Despite being formulated on several occasions, and taking into account the expected variations and changes in emphasis that that implies, Luhmann's theory of sociocultural evolution remained quite consistent and coherent over time. Beginning in the 196os within the framework of Parsons' sociology and his concept of "evolutionary universals," by 1975 Luhmann (1991; 1991b; 2017) had 
already laid the foundations of his social theory by binding together three self-referential theoretic approaches, namely, systems theory, communication theory, and evolution theory. Briefly sketched, it starts by identifying three evolutionary mechanisms: variation, selection, and stabilization. Communication guaranties variation thanks to the enormous combination and recombination capacity of the medium of language, and especially because of its potential for rejection. Selection has to do with favoring the possibilities of successful communication, as well as reaching more addressees than those present (that is, devising dissemination and success media). And stabilization is achieved by system formation and/or differentiation. The primary form of system differentiation (by segments, strata, or functions) is a key factor, because different system/environmental constellations will result in different conditions for selection and variation. In the same guise, technically developed communication media alter the conditions for evolution to evolve. And last but not least, variation secured by interdependence interruption and system differentiation increases the tempo of structural change, thereby accelerating social evolution.

Recent literature on Luhmann and social systems related to the issues of communication media and sociocultural evolution (and especially, underlining this very same triadic relationship) is strikingly scarce. Undoubtedly, some of most influential systemic thinkers following this thread are E. Esposito (2002, 2007) and D. Baecker (2013). Notwithstanding, the focus of these authors lies primarily on a sociology of knowledge of modern society. Of course, the same could be said of Luhmann himself. But even making some concessions (and exceptions: for example, the work of Giesecke (2002)), it is not far-fetched to affirm that there is a lack of genuinely historical interest in this field, because the emphasis is not on comprehending past societies by themselves.

On the other hand, criticism of the theory of communication media has focused on the alleged disregard or mistreatment of the problem of language (Kunzler, 1989; Schiewek, 1992), whereas others suggest that symbolic generalized communication media might not be media after all (Distin, 2012). However, I think there are two dimensions where Luhmann's approach is in need of further theoretical development, especially if what is looked for is to use Luhmann's theory for historical research. First, Luhmann (2012, p. 198) argues that symbolically generalized communication media are an outcome of sociocultural evolution and that they only emerge in complex functional differentiated societies, although some ancient complex societies developed pre-adaptive advances in this direction. But how then did communication media evolve? This is a genuine historical concern that has been insufficiently answered by Luhmann (although I do not insist that he should have provided an answer; his interests were other: a theory of modern society). Second, there is a graphocentric bias in Luhmann's assumption that only writing and printing press accelerated social evolution and increased social complexity (Luhmann, 1991, pp. 151-152; 1991b, p. 199; 1995, pp. 161-164; 2012, pp. 150-180). Were there no functional equivalents to writing and press throughout the history of civilizations? Many contingencies in the evolution of communication media may have been overlooked by Luhmann.

Part of the answer to the question of the evolution of communication media lies in the same oeuvre of which Luhmann is a part. The German sociologist argues that only advanced societies are in need of differentiating between the general language code and special symbolically generalized communication media (success media). At the same time, he affirms that writing made symbolic communication media possible; that writing allowed the differentiation between society and interaction; that writing is the condition of possibility of the formation of chains of power; that without writing, a logically schematized truth code would be impossible (Luhmann, 1979, pp. 110111). This means that Luhmann has taken for granted that dissemination media played a key role in boosting the differentiation of success media. If so, two remarks come immediately to mind: (a) because the invention of writing dates back at least to $3100 \mathrm{BC}$, it becomes apparent that an 
additional set of evolutionary universals was required for evolution to come up with functional differentiation, a very recent newcomer (1650-1750; Luhmann, 1980); (b) as a consequence, going beyond what is already known of Western history, the evolutionary drift between dissemination and success media requires further theoretical development in order to make Luhmann's theory a tool fit for observing ancient civilizations.

Again, some hints are present in Luhmann's writings. In order to explain the differentiation of communication media, the German sociologist developed two different strands of argumentation: With the differentiation of action and lived experience on one hand, and the potential for negation in language on the other, he intends to explain the emergence of success media; and with the differentiation between interaction and society, he aims to account for the evolutionary relevance of dissemination media.

Regarding success media, Luhmann takes recourse to a cross-tabulation where the axis of ego and alter intersects with the axis of lived experience and action. Hence, for instance, truth emerges when the experiences of ego and the experiences of alter are problematized, and so does power with reference to the actions of ego and those of alter (Luhmann, 2012, pp. 199-214). About the internal consistency of the theory, I think it is right to interpret this matrix as an evolutionary problem that every social system has to solve, without denying the complicated structure of preconditions required to reach a full structural development. That is, independent of its degree of complexity, every social system reproducing communication differentiates all of the four constellations of attribution (ego experiences-alter acts/ego acts-alter experiences/ego acts-alter acts/ego experiences-alter experiences) in order to develop expectation-structures that keep running the societal autopoiesis. I shall consider this as the source problem of communication media evolution (both, success and dissemination media), which certainly attains to the core of sociocultural evolution itself, namely, communication overcoming the improbability of reaching farther than presence and the improbability of achieving success.

But there is still no media here. According to Luhmann (2012, p. 202), a success medium begins to differentiate when attribution constellations develop into codes and the conditioning of selection becomes a motivational factor to participate in communication and when reference problems are fixed as well. Beyond this threshold, there are nine additional structural features success communication media (though not all of them to the same degree) have devised in the course of Western history: uniform code, self-placing of the code in one of its values, processual reflexivity, first- and second-order observation, programs, symbiotic symbols, inflation/deflation, symbolizing the inclusion of exclusion, and system formation (Luhmann, 2012, pp. 215-236). Attribution schemes play a crucial role in media emergence, and this is where historical research should focus: investigating what type of attribution schemes have become abstract enough to coalesce into a determined constellation (a reference problem) and motivate and codify communication; and then determining if coding has been followed by the mentioned structural features (which ones, on which sequence, how long it took to reach from one achievement to another, which elements accelerated or discouraged the process, and so on: These are the kinds of questions theoretically informed historians would ask). This would require deepening our knowledge of the relationship between coding and semantics.

Luhmann (2012, pp. 123-138, 150-180) also explains the emergence of success media as resulting from the need of evolving communication to induce acceptance under certain circumstances, provided that language code yes/no makes rejection highly probable, so putting the success of communication at risk, and with it, sociocultural evolution itself. This means that the conditions of possibility of success media rest on language, a sort of primary dissemination medium. Further, the Bielefeld 
sociologist suggests that language-based dissemination media act so as to prompt sense-making (Sinn)1 generalization by specifying conditions for conflict and negation having as a result an increase in complexity. These ideas support the thesis of the relevance of the evolution of dissemination media for success media to develop. Nevertheless, I think it should not be taken for granted that the binary structure of language alone can create the conditions of generalization of sense-making through the indeterminacy caused by negation. By reading Goody (1997) evolutiontheoretically, one can tell that almost any kind of representation can have similar effects (what Goody called cognitive contradictions). This thesis opens up new perspectives for historical research: Provided that not every language is equal in its structure and that its articulation with other dissemination media ought to be observed from its contingency (because not every dissemination media need to be language-based and if so the outcomes are different if what is represented is language itself or its reference function), it would be worth examining the performance of every empirically documented media configuration with regard to negation and sense-making generalization -taking for granted that this idea will rely on the assumption that sense-making generalization is directly responsible for symbolization and for complexity-building.

The case for dissemination media is presented by Luhmann as one where face-to-face interaction cannot surpass a certain complexity threshold, unless communication makes itself independent of human presence, which is achieved by the invention of writing and press. Writing and press bring about a whole new set of communication possibilities: They change the syntaxes of communication; it becomes possible to construct alternative realities by referring to what cannot be seen, let alone about what does not exists; they make temporal relations more complex; they increase the risk of rejection; they change the conditions for the setting of social memory; they contribute to the expansion of the dimensions of sense-making; they produce the closure of communication; they modalize communication; and they achieve symbolization (Luhmann, 1995, pp. 161-164; Luhmann, 2012, p. 173; Kieserling, 1999, pp. 226-238). Luhmann argues that writing makes possible a social system per se, that is, a communication system. Notwithstanding, it is quite plausible to think, even hypothetically, of other kinds of dissemination media that also increased social complexity in the past (see Hill Boone, 2000, 2012; Urton, 2003). The fact is that, without denying the importance of writing in the evolution of modern society, writing was not the only dissemination medium devised by sociocultural evolution in the course of human history. One could envisage that sociocultural evolution experimented with many mechanisms to trespass the threshold represented by presence and interaction; it tried with several media: Some were more successful than others, some experiments were forgotten, and some others persisted.

So far, I have intended to demonstrate that, to some extent, one can use Luhmann against Luhmann in order to make a historical-evolutionary reading of his theory of communication media. Departing from a universal evolutionary problem every social system must solve (that is, the need for actions

\footnotetext{
${ }^{1}$ The German word Sinn has been translated as meaning; however, I do not agree with this translation, even though Luhmann himself approved it. The concept of meaning in Luhmann is very close to that of Husserl. For the philosopher, meaning - as meaning-bestowing act and as intended meaning - is prelinguistic and stands as a guiding principle of language. Therefore, there is no point in distinguishing between Bedeutung (meaning) and Sinn (sense or sense-making). However, understanding meaning as prelinguistic and as conditioning language a priori induces Luhmann to confuse meaning and information, missing thereby an important distinction directrice to unravel the paradox of the distinction between semantics and social structure, a key feature of his social theory. I have proposed to understand sense-making as the unity of the difference between information (as defined by Shannon) and meaning (semantics in the proper sense), without contradicting the double form of meaning (sense-making, as I call it) as actuality and potentiality of actions and lived experiences. I have shown how this theoretical arrangement works in the case of totalitarianism observed under the distinction semantics/social structure (Blanco, 2018).
} 
and experiences to be coordinated and the expectability of other's action while one experiences and vice versa), there are two critical factors regarding the differentiation of communication media whose contingent development can tell us not only about whether a social system manages to differentiate media or not, but also what kind of media has evolved: attribution constellations/reference problems and the generalization of sense-making by negation through language or any other alternative representation system.

Nevertheless, Luhmann's theoretical framework still falls short in explaining how communication media emerged, especially in past societies. Therefore, I suggest that Luhmann's theory can be complemented if social systems are described as dynamic systems giving rise to attracting and repelling evolutionary trajectories, a theoretical insight he himself accepted (Luhmann, 2012, p. 12). Everything that nucleates the streams and flows of communication plays the role of attractors; every solution to functional problems (i.e. collective mandatory decision-making), every successful communication structure, and every ready-to-use attribution scheme, can cause an attracting dynamic to coalesce giving impulse to the complexity of the system by increasing the range of what is possible to communicate at the next moment. These evolutionary trajectories are to be understood as chains of recursive and chaotic event-like variations, which when self-organized into patterns give rise to structures capable of selecting other trajectories and stabilizing themselves as emergent dissipative structures. The emergence of communication media, as described above, can be conceived as an outcome of this process, which positively/negatively feeds back into itself.

Following Luhmann's thesis that evolutionary solutions making probable dissemination may put at risk other solutions making probable success and vice versa (Luhmann, 1995, p. 161), I envisage a theoretical description characterized by the structural drift between both dynamics. There are three possible overall outcomes: that each medium makes room for the development of the other, that they raise obstacles to each other's complexity-building chances, or a mixture of both. It is not possible to tell in advance what these obstacles consist of, and this is precisely what makes this thesis suitable for guiding historical research: The dynamic and its particularities need to be empirically identified.

Additionally, it is necessary to deepen into the luhmannian concept of dissemination media. For that purpose, the relationship between the following four factors must be taken into account: language, perception, what I will call "representation technologies," and representation materials. A representation technology describes a cultural feature consisting in the selection and working out of a representational framework, namely, sorting out whether to focus on perceptual features, linguistic features, or a mixture of both. If centered on mere perception, it will be called a "semasiographic representation technology." If centered exclusively on language, there is a choice to be made: If sounds are to be represented (which will require classifying sounds and deciding if attributing a sign/symbol to each of them), it is a "glottographic representation technology," but if what is intended to be represented are conventional cultural meanings, it will be an "ideographic representation technology." Glottographic and ideographic representation technologies can conflate into one; on the other hand, mixtures between semasiographic and glottographic representation technologies are rare. In any case, any of these mixed configurations will be called "polygraphic representation technologies.” Furthermore, representation materials are usually considered secondary or even unimportant, yet still in sociocultural contexts materials are not value-free, not meaningless. If some kind of symbol is represented on wood, leather, gold, stone, ceramics, and mud, among other material media, additional information is being conveyed underlining rank, pageantry, publicity, privacy, sacredness, veneration, desecration, formality, informality, and so on, everything depending on the importance the culture under consideration attributes to particular materials. Consequently, material media can also work as to change information and meaning, 
becoming a source of variation, semantically and socio-structurally. In short, the selection of representation technologies and representation materials constitute outstanding contingent features that Luhmann's model left unexplored.

I think this framework will give insight into one of the cultures that has most fascinated Andean archaeologists during recent decades: the Moche.

\section{The Moche}

Since Max Uhle and Rafael Larco Hoyle first described this civilization, major changes in the way the Moche culture is interpreted have been driven by recent excavations. For instance, some archaeologists are reluctant to talk about the Moche as an ethnically homogenous community. Makowski (1994) suggest that Moche settlements in the Piura Valley can be best described as multiethnic. Others refer to different origins of the Mochica reaching back to the Salinar, Gallinazo/Virú, and Vicús cultures, which previously spread through the Peruvian North Coast, some of them may have even coexisted with the Moche (Béslile, 2008, p. 22, 26; Castillo Butters et al., 2012, p. 6o; Castillo \& Uceda, 2008, p. 707; Shimada et al., 2008, p. 188). Many agree that Mocheness was essentially an elite ideology and religion (Bawden, 1996; Swenson, 2014, p. 42; Quilter \& Koons, 2012, p. 138; Castillo \& Uceda, 2008). Lineage elites gathered influence by staging rituals and sacrifices at the top of the huacas, while providing public feasts where liters of chicha (Andean maize beer) was drunk and llama meat (a species of Andean camelid) was eaten and by distributing fine ceramic, ocarinas, whistles, and figurines for the commoners to perform libations and fertility rituals at their homes and on their lands (Swenson, 2006; Ringberg, 2008). Currently, archaeologists tend to recognize Mocheness as an archaeological construct, though a plausible one owing to the distinctive character of their material culture (Quilter \& Koons, 2012; Castillo Butters \& Uceda, 2008).

Even more doubtful is to describe the Moche as a single unitary state ruled by a powerful elite of priests and military (Larco Hoyle, 2001; Moseley, 2001). The thesis of one single Moche state has been succeeded by a thesis of two Moche states (northern and southern; Bawden, 2001; Castillo Butters \& Donnan, 1994; Donnan, 1996; Kaulicke, 1992; Shimada, 1994), and more recently by strong denial of political centralization. Many terms trying to describe and explain the diversity of the political organization of the Moche have been coined, such as "multiple polities" (Quilter, 2002, p. 155), "valley-states" (Benson, 2012, p. 27), “opportunist states" (Castillo Butters \& Quilter, 2010), and "huaca communities" (Dillehay, 2001, p. 267), among others.

Some other features still remain subject to debate, as to whether the southern Moche polity was an expansive, militaristic state or if warfare was predominantly ritualistic and/or confined to occasional low-intensity internecine events (Quilter, 2002, pp. 167-172).

Nevertheless, beyond archaeological discoveries, debates about Mocheology have raised cogent theoretical and epistemological issues. As Castillo Butters (Castillo Butters \& Uceda, 2008, pp. 709710; Castillo Butters et al., 2012, pp. 55-56) have put it, the predominant one-dimensional view of society (as having one form of organization, one identity materialized univocally on the archaeological record, one way of doing things, and on top of that reducing society to the expression of its elites) prevailing in archaeological research hinders reaching a broader view that reflects the true complexity of ancient societies. Societies are multidimensional and often exhibit wide variation in their material culture. Social groups interact in complex ways not necessarily being represented by their rulers or elites, neither political evolution is to be seen as a cumulative, linear, and necessary process. 
I would add that thinking of the unity of society as political is also a misguided assumption. Conflating with politics sociostructural problems, such as aggregation of segments into greater social formations and the concomitant appearance of inequalities, only confuses our theories of social evolution and encourages the use of anachronistic and Eurocentric categories of analysis (such as, for instance, state, city, and so on) that impede the social scientist's comprehension of a culture on its own terms or at least on its specificity. While holding to these categories, even the most reasonable generalizations yielded by cross-cultural analysis become limited in scope.

I propose that the best way to understand an alien culture, and concretely the Moche, is to subsume it into a broader dynamic system (I would call it a "regional social system"), wherein a set of interacting communication media struggle to expand and survive entropy. If variations are seen as trajectories of concatenated communication events, successful communication can be understood as attractors that select further communication. In this guise, a regional social system develops attracting dynamics around which social trajectories revolve, as well as repelling dynamics that describe diverging trajectories. Communication media arise out of these dynamics by working as selection mechanisms that may also give rise to bifurcations creating dissipative structures of variable endurance, robustness, and complexity.

Accordingly, the Moche will be described as a set of loosely articulated social formations embedded in a greater regional Andean structure, where different social trajectories gave rise to particular dissemination and success media that reached a certain level of complexity and differentiation. These media interacted among them, coalescing and diverting, having as an outcome different dissipative structures of variable endurance and potential of stabilization, during the Moche culture's roughly 650 years of existence.

Dissemination media, materialized on architecture, pottery, textiles, and metal work, managed to expand its reach across northern Peru aggrandizing the Mocheness identity, practices, and beliefs. At the same time, Moche social structure can be read as a set of provisional solutions to crucial socioevolutionary problems, such as the coordination of actions (a matrix out of which power evolved as a success medium in the Western world) and the coordination of experiences (a matrix out of which truth emerged as a success medium also in the West; Luhmann, 1979, 1991c, 1992). These media have left utterly recognizable traces in the material culture, although deciphering specifically what they meant to their creators and users poses a much more difficult task than determining how they came to produce meaning in the first place.

\section{The evolution of communication media in the Moche world}

It is a commonplace that the Moche cannot be understood unless contextualized in the range of Andean developments during the Early Intermediate period (40o BC-550 AD) and the Middle Horizon (550-900 AD). Certainly, the North Coast evolved into a single region defined by its peculiar characteristics, though this dynamic was embedded into a broader interaction between the highland and Amazonian regions. The Coast, Andean highlands, and Amazonian basin formed a sort of transmission chain that moved people, goods, and beliefs in both directions. It is well known that the influential "settled ceremonial center" (Makowski, 2006) of Chavín de Huántar exhibited in its iconography motifs of Amazonian provenience. Chavín de Huántar, in turn, influenced religious belief systems Andean-wide. Specifically on the North Coast, Chavín motifs are seen in the Cupisnique culture (1200-200 BC), the same cultural matrix from which the Moche consciously projected back their ancestral origins and whose ceramic style (stirrup-spout bottles) they imitated (Benson, 2012, pp. 12-19). 
I take the term "settled ceremonial centers" coined by Makowski, because it is not only a surrogate for city in order to describe more accurately certain kind of settlement patterns, but also because it refers to a long-term evolutionary trajectory in Andean sociocultural evolution. Places such as Caral, Chavín de Huántar, Tiahuanaco, and Pachacamac were prestigious ceremonial centers that attracted thousands of pilgrims. The Huaca of Pachacamac (in this case a mighty oracle instead of a pyramid in itself) on the central Coast, for instance, was of such importance that is was occupied and its cult maintained by several cultures, such as the early Lima, the Wari, and finally the Inca. It is therefore plausible to suggest that the dynamic system described here, made of "settled ceremonial centers" an attractor of different social dynamics (in a similar sense Quilter (2002, p. 176; Quilter \& Koons, 2012, p. 137) referred to centripetal and centrifugal forces in order to explain the social dynamics involving the huacas). That is, on them converged identities seeking control (White, 2008), networks of barter and trade, and reciprocity links (Galarschelli \& Lodoffredo, 2004) leading to asymmetries (Mauss, 2009), on which basis the problems of the acceptance and dissemination of communication became acute, inducing evolution to push forward new experimental solutions.

\subsection{Power}

One of the outstanding characteristics of settled ceremonial centers, such as Caral, is that they were built without the existence of a centralized political authority to coordinate labor, or even to demand it by coercion. It is so puzzling how a society can possibly reach such a level of complexity without a state-like organization that some archaeologists cannot conceive of such deeds but as the result of state-activity. The same is seen in Mocheology. Those who hold the thesis of a Moche state, whether single or southern-based, (Chapdelaine, 2000; Moseley, 2001; Topic, 1977; Uceda \& Meneses, 2016) cannot explain the degree of social organization seen in Huacas de Moche except as the result of centralized political authority. On the contrary, the "huaca community" thesis of Dillehay (2001) seems a more plausible explanation, as I expect to demonstrate.

Still, greater distance from this debate is needed in order to make our point. Starting from the principle that the matrix out which power emerges is the problem of coordination of actions, it becomes relevant to track the expectation-structures that made it acceptable in the ancient Peruvian North Coast to follow another's deeds or even to follow another's commands. The first thing to consider is the degree of differentiation between social structure and power organization. What is seen in ancient societies, such as the Moche, is that power is either poorly organized or not organized at all, and that trust and all of the power resources needed to gather influence are embedded in the domestic realm. As a consequence, a closer look into Moche social structure is needed.

Moche social structure was primarily differentiated in segments. That means that, although hierarchy structures were developed, lineages had the functional primacy. The Moche used dress to identify maternal (belts) and paternal lineages (headdresses; Golte, 2009, pp. 74-75; Benson, 2012, p. 27). In the same guise, segments had a dual structure expressing a long-lived Andean cosmology; some call this dual organization parcialidades, others prefer the Quechua term ayllu (Netherly, 1990). The dynamics of these interacting segments gave rise to social formations of diverse complexity along the Moche territory. The attractor that favored cooperation and alliances of different kinds (marriages, for instance) was the construction of canals to water the dessertic plains to grow crops such as maize, beans, chilies, among others, and the construction of huacas.

Irrigation was vital for survival, and it has been proved that its development raised the complexity of coastal social formations (Billmann, 2002; Gagnon, 2008). Contrary to Wittfogel's affirmation, irrigation systems did not lead to large authoritarian states. Instead, irrigation systems were initially built locally by extended families. Larger projects naturally required the cooperation of several 
segments, although there were no central political authorities directing the construction. This means that there were well established social patterns of cooperation among lineage groups.

On the other hand, the construction of labor-intensive huacas had different motivations. There are three plausible and interrelated hypotheses. The first is sheer cooperation motivated by the worship of common ancestors. For ancient Peruvians, mountains and other geological formations were considered their petrified ancestors or apus. The need for propitiation and protection against natural disasters might have been sufficient motivation. But it is also possible that some segments gained influence by means of successfully linking themselves to prestigious ancestors. Accordingly, they demanded some kind of tribute (labor but maybe also food) in return for magical protection and fertility propitiation. And third, by building huacas, they might have been following a tradition inherited from their ancestors. So, it could have been considered a communal duty.

Once huacas were built and their prestige as pilgrimage centers had grown over time, asymmetrical reciprocity links sprouted up, prompting dependency relations. Huacas de Moche and Huaca de Cao Viejo in the south and San José de Moro in the north were indeed such places at the paramountcy of Moche culture. For certain, this dynamic of attraction was a suitable locus for the growth of influence as a communication medium, especially authority as a favored form of generalization of influence, but without excluding reputation and leadership as possible sources of disruptive dynamics (Luhmann, 1979, pp. 156-157).

The staging of rituals symbolized and generalized influence to some degree (Swenson, 2011), because it operated as a form that became undetermined (the variable social meanings attributed to it each time the ritual was performed, depending also on the social groups involved and their actual mutual relationships) in its determination (the structure of the ritual as a set of predetermined, stylized, and ordered actions). It might be regarded, in fact, as a technicization of the transmission of reduction. But the crucial point to structuring power as a medium is the imposition of positive and/or negative sanctions. Hocquenghem (2008) argues that some practices of sacrifice, specifically those involving severe mistreatment of captives, might be considered as punishment. If this is true, some kind of negative sanctions may have been wielded by the religious elites. Still, it is improbable that priest elites monopolized the capacity to impose negative sanctions. Lineage dual structure of authority surely played an important role in the punishment of transgressions (uruiñ in Muchik). On the other hand, public feasting involving people of different ranks might be considered as some sort of positive sanctions (Swenson, 2006). Conspicuous consumption was surely a sign of wealth, a mechanism of social redistribution, and a hallmark of prestige. But a monopoly of this kind of sanctions might have never happened in Mochelandia. The Moche territory was populated with huacas where feasting and sacrifices probably took place. Certainly, Huacas de Moche might have been one of the most influential loci, although during the Late Moche period it suffered an important decay. Similarly, farther north, feasting and terraced altars spread through the periphery, leaving the elite in San José de Moro in the Jequetepeque Valley without their former source of influence and in need of reinventing their social primacy (Swenson, 2012; Castillo et al., 2012).

However, the most significant evolutionary trajectory that this huaca-centered dynamic left is that this kind of monumental architecture became a pole for pottery, metal work, and textile production, as well as locations where astounding visual displays were exhibited. These settled ceremonial centers produced fine wares for the elite and intermediate goods for the populace (Bernier, 2010), creating barter networks that may have sustained semi-permanent urban populations in the most important centers, such as Huacas de Moche and Huaca de Cao Viejo, and lately urban-like centers, such as Galindo and Pampa Grande. On the other hand, there is a wide consensus among Mochicologists that, especially in the iconography displayed on ceramics and on the architectural 
layout of religious monuments, an ideological program was consistently exposed. To be precise, many archaeologists figuratively speak of these expressions as communication media (Bernier, 2010, pp. 31-32; Lockard, 2008; Ringberg, 2008, pp. 352-353; Golte, 2009; Billman, 2010, pp. 185-186, 193; Koons, 2015, p. 476; Moore, 1996, pp. 221-227; Gamboa, 2008, p. 204; Uceda \& Meneses, 2016). Fortunately, observing artifacts of the material culture as communication media is not an unusual perspective anymore in social sciences.

My hypothesis is that settled ceremonial centers unleashed a dynamic where the action of dissemination media like these produced positive and negative feedback trajectories reinforcing authority and leadership but also causing fragmentation, as expressed in the diversity of regional ceramic styles as well as in different local appropriations of the Moche liturgy (Koons, 2015; Swenson, 2011). When trajectories were reinforced, influence was transformed into power, because pilgrimage centers as such, condensed meaning and increased redundancy for communication to continue, making mandatory decision-making independent of too concrete conditions; but the lack of organization and sufficient symbolic generalization to stabilize expectations on the imposition of sanctions caused this power concentrated on religious symbolism to soon be scattered.

\subsection{Moche dissemination media}

Studying Moche pottery as art (Bourget \& Jones, 2008; Benson, 2012) might be misleading. If it is assumed that Moche art is veristic (and as a consequence that it might represent historical events), that Moche artists had canons but were also creative, that Moche artists intended to represent something/someone, and that they were selective as to what to represent on murals and vessels (Quilter, 2002), the historian would be projecting on an ancient society criteria that belongs to our time, to our functional differentiated society, that is, ideas that do not fit easily into ancient social systems. Moche material culture undoubtedly has an aesthetical value for us, but we cannot readily assume that the Moche regard their artifacts aesthetically; this has to be proved. Obviously, the Moche were able to perceive, for example, that the man and the portrait-vessel that imitated him were not the same. But if one accounts for what they thought they did when they shaped paste into different figures and forms (and I am referring here to self-observations/self-descriptions), they probably believed, as ethnologic studies suggest, that they were giving birth to something or reproducing the timeless life force of nature (camay or camac in Quechua) that transpired through objects, animals, and people (Golte, 2009, p. 69). So, when they modeled something, they were capturing or invigorating the camay, strong animate, from the camasca, a being or animated object, in order to continue the cycle of life2. How then to conceive of Moche material culture if not as art?

Following Luhmann, a functional system for art only differentiated after code and programs coalesced into a reference problem excluding everything else. Otherwise, "art" remains subservient to other functional systems earlier differentiated. But what was the fate of art as a function, not as a concept, when there were no functionally differentiated social systems? The reference problem, for which no particular system was accountable, was the continuance of perception-guided communication. Autopoiesis of this kind has been usually achieved by using forms as a medium for further formations (Luhmann, 2000, p. 109, 142). Accordingly, any kind of self-organizing

\footnotetext{
${ }^{2}$ Hocquenghem (2008, pp. 25-26) affirms that the Huarochirí believed that the ancestors, depending on the prestige and strength of its cult, possessed different abilities to animate and sustain life; therefore, the camasca had to pay tribute to their ancestors so the camac would keep animating life and even accumulate strength; the Huarochirí believed that camac had three roots: callpa (communication, memory, and knowledge), sinchi (bravery and physical power), and capac (wealth, opulence, and generosity). It is not for nothing that organizing feasting and/or offering, so to speak, "shamanic services" were sources of social authority in Andean social formations.
} 
communication structure that reproduced itself through the difference of medial substratum and form, and that has found itself within the attraction dynamic of other medium/forms constellations in a fractal-like manner, constitute the domain of the conditions of possibility for art. Furthermore, this implies that "art" grew out of the domain of dissemination media, because any media served for the purpose of communication whether amplifying or restricting the range of potential addresses for communication. In short, it is not far-fetched to treat material culture as communication media, especially dissemination media.

Support for this point of view is found in the literature of Mochicology. The fittest argument considering pottery as a communication medium derives from J. Golte's (2009) iconographic interpretation. Golte argues that tinku (Quechua word for encounter) is a fundamental concept in Moche cosmology. The world was divided by the ancient Moche into a set of dualities (day/night, earth/sea, masculine/feminine, north/south, east/west) that crisscrossed to form "planes of existence," so to speak; the day was masculine/masculine; the night masculine/feminine; the earth feminine/feminine; and the sea feminine/masculine. Accordingly, a tinku defines an energetic and lively encounter between planes. Warlike tinku and peaceful tinku as well, set forth the animating force of nature. Ergo, shape and function of earthenware was related to the propitiation of tinku. Some type of ceramics were designed as offerings to the upper world (bowls, for instance), some as offerings to the earth, some other as offerings to the world of the dead (that for the Moche laid down the sea), and so on.

During Moche III-IV (a chronology set by Larco Hoyle based on ceramic styles, 400-650 AD), the site of Huacas de Moche was testimony to the emergence of a singular kind of ceramic, characterized by the high quality of its paste and its narrative depictions. Following previous research by Hocquenghem (1987) and Quilter (1997) among others, Golte suggests that these ceramics possess a narrative structure describing Moche myths and a ceremonial calendar as well. Furthermore, Golte (2009, pp. 27-53) affirms that there is a proper way of reading Moche pottery. The ceramic has to be considered as a three-dimensional medium. In principle, every vessel has to be divided into four faces. The more elaborated stirrup-spout bottles must be additionally divided into four planes in the frontal face and four more in the rear one. The stirrup-spout itself incarnates the tinku, for it is not by chance that some icons are linked to others through this feature. By means of this threedimensional constitution, the ceramics also replicate the Andean philosophy of complementary oppositions, ergo it is neither by chance that some figures and icons appear in one face and others in the opposing one. In short, ceramics can be seen as a medium for codifying information.

I think Golte demonstrates compellingly how the Moche used pottery to express their beliefs, myths, rituals, and ceremonies. A further dimension is added if we consider that this earthenware also played a role in the rituals and ceremonies they depicted. These ceramics surely were not simple objects for them. They had some kind of magic effect; they were pragmatic tools in the realization of the rituals. It is plausible to think that, while being used during ceremony, they came to incarnate the life force of the objects and/or subjects depicted on them. They might even have been considered as having a life cycle of its own, living and dying.

These items were produced on a massive scale at settled ceremonial centers and probably distributed in exchange for camelids, food, and luxury goods, such as Spondylus and Strombus shells.

Distribution made available to new believers the customs and religious pantheon of the Moche materialized on vessels, bottles, figurines, ocarinas, and rattles, keeping them plugged to a steady supply of cult items. These beliefs also expressed themselves in architectural layouts along the Moche territory, especially on the iconography displayed on their murals. It should also be noticed that rituals and ceremonies structured the life of the Moche people, telling them what to do, when, 
and by whom (from this point of view, one can think of the function of dissemination media in temporalizing complexity, but that is a point I cannot develop further here). As a result, a relatively stable set of normative expectation structures or customs was surely created. This is how the Moche expanded and a Moche identity came about.

\subsection{Truth}

Being the matrix-problem of truth and the coordination of experiences, it is almost impossible not to see its evolutionary opportunities as linked to the religious dynamics. This seems to be a common pattern in sociocultural evolution. But before diving into religion, it is important to emphasize that, in social formations primarily differentiated by segments, the problem of truth is one of normative expectation structures and its stabilizing function in interaction systems. This is why the words meaning truth (llaerraep in Muchik or checcancay sullullcay in Quechua) are commonly nested in a semantic field relating to honesty, to speak frankly, to give one's word, not hiding any intention, not intending to cheat, and so on. In other words, truth is a matter of trust and, in this sense of coordination of actions, it is interesting to see how far the semantics are from the sociostructural problem we are investigating.

So, how did the Moche solved the problem of coordinating experiences or of creating common and/or consensual experiences? There were certainly several functional equivalents. Still, one of the solutions devised in the world of the Moche is related to the trajectory that leads in the West to the differentiation of a functional system for science. That is, knowledge.

Luhmann (1987, pp. 40-53; 2008, pp. 165-170) has repeatedly pointed out how crucial, in sociocultural evolution, is the modalization and differentiation of normative and cognitive expectations. It is very difficult to make inferences of this kind for a culture without writing, although Moche iconography has something to tell despite the embryonic state of iconographic studies. As Golte (2009) continually hints throughout his work, the Moche expressed on their iconography a deep understanding and knowledge of the north coastal natural environment. By analyzing the icon of the Spider, Nestor Alva (2008) reaches a similar conclusion. As a consequence, it is not far-fetched to suppose that Moche pottery somehow served to enliven knowledge becoming available for new generations. It might have not been about Moche children learning from vessels though. The pottery probably expressed things known to everybody (maybe this was the sense of the Moche word for knowledge, kankapissäk, but it might also have had expressed some transcendental and religious wisdom). Tribes that traditionally practiced a craft (as might have been the case with metalworkers, (Swenson \& Warner, 2012)) taught their know-how to new generations, as did corporate groups, if they really managed to differentiate, as Bernier (2010) suggests. Still, iconography probably fed back to that knowledge, reinforcing it. This way it also helped structure Moche communitarian life, because that knowledge was related to the performance of seasonal rites.

In summary, my hypothesis is that dissemination media, once furthered by the medium of influence/power, played an important role in profiling an evolutionary path favoring the differentiation of a more or less generalized symbol orienting the acquisition of knowledge. But at the same time, the unique constitution of this medium set limits on this development. In order to examine the nature of these limits, I propose to discuss the following two issues:

- How informative were Moche dissemination media?

- How did they represent negation, and consequently how did they contribute to the condensation and generalization of sense-making (Sinn)? 


\subsection{Truth and ceramics}

A communication medium produces information. It does not transmit it. This means that the peculiar constitution of medium and form engenders a determinate surplus of possibilities unique to that medium. Referring to Moche pottery, this implies that it had a peculiar form to produce signification, which depended on its capacity to hold together simultaneously an actual selection and a certain number of possibilities (information). A medium has to produce and balance redundancy and variety in order to fulfill its functions. This is what I mean by asking how informative Moche media were.

Luhmann (2002, p. 173) argues for the utterly visual attraction of writing. For him, writing was capable of focusing attention in such a way as to displace other media. I think this is not necessarily the case. Social communication is unassailably multimedia, namely, it jumps unquietly from medium to medium, usually stitching several of them together at the time communication is performed. I think a three-dimensional medium like Moche pottery, could have been much more attractive to the perception of psychic systems. On the other hand, Gary Urton (2003) affirms that the Inca Khipu may be considered as a form of writing with an information storage capacity of 7 bits, accruing up to 1536 potential information units. A similar case of binary coding could be made for Moche pottery. Following Golte (2009), it should be taken into account the shape of the earthenware and dimensions such as inside/outside, front/rear, up/down, and if and how the stirrup-spout expresses the tinku by linking two depictions. Thus, one could calculate at least 5 bits of information storage capacity. Of course, the actual information and meanings "produced" by the medium depended on the context they employed. In any case, information-capacity is obviously a substantial feature if knowledge-gain is to avail of dissemination media. But is this enough?

There are at least five preconditions to an evolutionary pathway such as that covered by the Western world, all of which contributed to a prompt sense-making generalization, that can serve as comparison criteria: (a) the selection of a glottographic representation technology, (b) the differentiation between normative and cognitive modalizations, (c) coding, (d) regional fragmentation of power structures, and (e) the differentiation between society and interaction.

a) The first precondition would be selecting among a range of possibilities (that is semasiographic, ideographic, and glottographic) a representation technology that represents language in its very structure, that is, a glottographic representation technology. That is a contingent choice, and its importance lies in the ability of language to generalize sensemaking through an ever-present rejection capacity (Luhmann, 1981). Nevertheless, as I mentioned earlier, every form of representation always keeps present the possibility of negation (Goody, 1997). The question is how and if it succeeds in generalizing negation so as to codify communication attending to a truth-value. The problem is that not every kind of representation can specify rejection so as to interrupt interdependencies by conditioning and specifying cases/contexts for contestation. As far as we know, the Moche had no sign for "No" in their iconography that could have been used to tell alternative narratives while refuting those opposing it, or even more remarkable: to refute some specific features while accepting the rest. The fact that contradiction was non-contradictorily included in Andean dual cosmology further complicates the matter. So how did the Moche social system make negation available? The first thing to be settled is what kind of representation technology the Moche developed. The archaeological evidence strongly suggest that they had a "semasiographic representation technology," but it should also be taken into account how these artifacts were used: Some were designed for mortuary purposes, others for domestic rituals, some were crafted to produce sounds (so it can be assumed that music played some 
role), and many of them were reserved for elite usage. Therefore, one should think of multimedia communication contexts. How is rejection to be performed under multimedia contexts? Archaeological evidence provides some hints. (i) There is a certain correlation between the period of decay of Huacas de Moche, changes in the iconography, and the founding of new settlements, such as Pampa Grande and Galindo, suggesting shifts of dominant elites (Benson, 2012; Chapdelaine, 2000; Bourget, 2001; Uceda, 2001; Lockard, 2008). (ii) The blooming of the San José de Moro site is related to the discovery of earthenware of Cajamarca and Wari provenience, suggesting barter, social, religious, and possibly political links with nearby highland settlements (Swenson, 2012; Castillo Butters et al., 2012). (iii) At the Jequetepeque, there was a proliferation of terraced platforms for ritual purposes during the Late Moche period, suggesting a highly decentralized social formation (Swenson, 2006). From this some inferences can be risked: Social contradictions and conflicts affected iconographic programs, and these in turn were intended to support authority structures, whether traditional or recently established; as the case of San José de Moro demonstrates, the adoption of foreign icons could have been used as a new source of prestige, but these icons should not have been in plain contradiction of those of the Moche tradition, being thereby integrated within a new narrative (Castillo Butters et al., 2012); different meanings were attributed to Moche iconography according to place and social strata, as the case of Jequetepeque suggests. I shall conclude that contradictions among iconographic programs were solved: either by absorbing dissonances within the multimediatic context of ritual, where the new was tamed by means of the redundancy of the already known; by breaking with existing patterns, whereby new social structures were accompanied by innovative iconographic programs and even by new crafting techniques; or simply by abandoning what was no longer considered valid, so the artifacts could be intentionally destroyed or incorporated in new multimediatic contexts where they acquired new meanings and new forms of making sense.

b) Archaeological evidence on social organization might yield some hints about the un/differentiation between normative and cognitive expectations. As already noted (Golte, 2009), the Moche possessed a very detailed knowledge of the ecology of the Peruvian North Coast; and rituals, and the depiction of rituals on pottery, murals, and even textiles, were somehow used to codify that knowledge. Unfortunately, there is little else I can say without the risk of speculation. How the Moche produced and transmitted knowledge is something we just do not know.

c) For truth to become a success medium, it is not only necessary to devise binary schemes and codes, but also that these ought to re-enter the medium resulting in the appearance of selfreferential loops. In that event, the crafting of second-order observation techniques applied to cognitive expectations, bring as an outcome cognitively expected cognitive expectations, or simpler, the ability of learning to learn. Here lies the condition of possibility for a functional system for science. The crucial factor is that glottographic media apparently had a better chance of becoming reflexive than negation effectively furthered generalization of sense-making (which means more possibilities available and, as a result, more contingency). Interestingly, however, pottery was depicted on Moche pottery, displaying some kind of selfreference or even a sort of re-entry of the form into the form. Could have the Moche developed some kind of second-order observation by means of this type of dissemination medium?

d) The fourth precondition would be a regional fragmentation of power structures, so the evolution of dissemination media earns more degrees of freedom, that is, by escaping from control attempts on behalf of power structures, it gains more possibilities to explore. Too centralized regional power structures, as seen in the history of imperial China, can ruin the 
possibilities of complexity-gain of dissemination media. Political fragmentation also means more possibilities to make symbiosis with other success media, such as truth. But too much fragmentation could result in the absence of standardization pressure, a decisive factor in the dissemination of dissemination media. In this case, it is becoming clear that the Moche influence/power structures were too fragmented.

e) The fifth precondition would be the differentiation between society and interaction. But because this difference is always present in every social system, it is a matter of degree and structuration, that is (i) communication reproducing itself without assistance of human presence, (ii) how different communication media relate to interaction, and (iii) how interaction condition media communication (Kieserling, 1999). When interaction systems predominate, multimediality - or as Brokaw (2010) puts it, polygraphy - tends to thwart media differentiation, a feature commonly seen in multifunctional social systems. In the Moche world, multimediality probably took the function of producing redundancy, then the same icons iterated through different media reinforced some kind of deep meaning. Maybe in this sense multimedia was tantamount to a transcendental truth. In any case, if dissemination media cannot gain more degrees of freedom to develop independently, at best to a considerable degree, emergence thresholds cannot be exceeded and complexity is not heightened. Moche dissemination media undoubtedly boosted social complexity, but how this complexity displayed in the different sense-making dimensions needs further clarification.

\section{Concluding remarks}

As we have seen above, various media take important Truth is an outcome of sociocultural evolution; an evolutionary universal outdifferentiated from a surplus of communication possibilities for lived experience; a symbolic generalization that gave rise to the outdifferentiation of a functional system for science, thereby producing in turn new surpluses of possibilities for communication, at least for our modern society. In fact, this is a contingent description of a contingent evolutionary process. For truth to accomplish the function it performs for modern society, sociocultural evolution had first to experiment with a wide range of solutions for overcoming its own improbability (for communication to be understood, to be disseminated beyond the domain of human interaction, and to be accepted). Hence, dissemination and success communication media constitute the driving force of evolution: the immediate source of complexity bursts and social differentiation, and de-differentiation and complexity loss as well.

I have employed the case of the Moche in order to show how success and dissemination media can be described as being involved in major attracting/repelling dynamics of strings of communicative events, bifurcating, temporalizing (accelerating/decelerating), and producing dissipative structures that in turn open up new possibilities for autopoietic reproduction. Concretely, "settled ceremonial centers" emerged as a first attractor around which many structures of influence/power, structurally coupled to segmentary social formations, with different degrees of complexity coalesced, favoring and being favored by earth-, textile- and metal-based dissemination media (especially earthenware), having as a result what can be called Mocheness: a set of stabilized normative/cognitive structures for communication, characterized by typical iconographic programs, distinctive artisanry, and architectural styles ... in a nutshell, a socio-systemic identity defined by a set of experimental and, by then successful, dissemination media.

As I said before, the goal of this essay is not to explain why the Moche did not have science, but what can we learn from social evolution by studying their culture. In this sense, I think this research has left many questions open that deserve further investigation (empirical and theoretical as well): 
- The difference between code and semantics: To account for how attribution constellations may condense into binary schemes and these in turn into codes, it is necessary to explain theoretically and empirically how semantic structures may turn into codes and if codes in turn can vary semantically.

- Dissemination- negation- complexity: How dissemination media based on semasiographic, glottographic, ideographic, and polygraphic representation technologies, respectively, behave in relation to sense-making generalization by recurring to negation, contradiction, opposition, and the like, and how every resulting setup conditions the relation of degrees of complexity between the social system, the systems in its environment, and its ecological environment.

- Regional social system and stabilizations: Why were some cultural advances lost? The answer lies probably in the failure to stabilize selections at the level of the regional social system. But how does this occur? What processes are at stake? This is something to be explained for the Moche in particular and for social evolution in general.

- Multimediality- multifunctionality- interruption of interdependences: It remains to be determined to what extent multimediality is equivalent to multifunctionality and if it offers or precludes chances for the interruption of interdependences; to what extent it allows or impedes attribution constellations to converge with reference problems; and if the condensation of meanings and possibilities for action and experience it renders, trigger solutions involving temporalization of complexity.

- Other success media: I was interested only in truth (which was inevitably linked to power structures), notwithstanding attracting/repelling dynamics involve the whole range of success media. Their interaction deserves further research.

- Self-reference: Re-entries, such as those performed in Moche iconography, need to be explained concerning their function and the extent to which they can be considered an indicator/factor in social complexity. If so, what can this tell us about the Moche?

\section{Acknowledgement}

I thank the reviewers and editors for their thoughtful and helpful comments on earlier versions of this article.

\section{References}

Alva, N. (2008). Spiders and Spider Decapitators in Moche Iconography. In S. Bourget y K. Jones (eds.), The Art and Archaeology of the Moche (pp. 247-261). Austin: University of Texas Press.

Baecker, D. (2013). Beobachter unter sich. Berlin: Suhrkamp.

Bawden, G. (1996). The Moche. Oxford: Routledge.

Bawden, G. (2001). The symbols of late Moche social transformation. In J. Pillsbury (ed.), Moche Art and Archaeology in Ancient Peru (pp. 285-305). New Haven, CT: Center for Advanced Study in the Visual Arts Symposium Papers XL, National Gallery of Art, Yale University Press. 
Bélisle, V. (2008). El horizonte medio en el valle de Santa: continuidad y discontinuidad con los mochicas del intermedio temprano. In L. J. Castillo Butters et alia (ed.), Arqueología Mochica. Nuevos enfoques (pp. 17-32). Lima: PUCP/IFEA.

Benson, E. (2012). The Worlds of the Moche on the North Coast of Peru. Austin: University of Texas Press.

Bernier, H. (2010). Craft specialist at Moche: organization, affiliations, and identities Latin American Antiquity 21(1), 22-43.

Billman, B. (2002). Irrigation and the Origins of the Southern Moche State on the North Coast of Peru Latin American Antiquity 13 (4), 371-40o.

Billman, B. (2010). How Moche Rulers came to Power. Investigating the emergence of the Moche Political Economy. In J. Quilter y L. J. Castillo Butters (eds.), New perspectives on Moche Political Organization (pp. 181-202). Washington: Dumbarton Oaks Research Library and Collection.

Blanco Rivero, J. J. (2018). Historia conceptual y social del totalitarismo. Una propuesta teórico-metodológica. Convergencia. Revista de Ciencias Sociales, 76, 99-118.

Bourget, S. \& Jones, K. (ed.) (20o8). The Art and Archaeology of the Moche. Austin: University of Texas Press.

Bourget, S. (2001). Rituals of sacrifice: Its practice at Huaca de La Luna and its representation in Moche iconography. In J. Pillsbury (ed.), Moche Art and Archaeology in Ancient Peru (pp. 89-110). New Haven, CT: Center for Advanced Study in the Visual Arts Symposium Papers XL, National Gallery of Art, Yale University Press.

Bourget, S. (2006). Sex, Death, and Sacrifice in Moche Religion and Visual Culture. Austin: University of Texas Press.

Brokaw, G. (2010). Indigenous American Polygraphy and the Dialogic Model of Media Ethnohistory 57(1), 117-133. http://doi.org/10.1215/00141801-2009-056

Castillo Butters, L. J. \& Donnan, C. (1994). Los Mochicas del norte y los Mochicas del sur: una perspectiva desde el Valle de Jequetepeque. In K. Makowski (ed.), Vicús (pp. 143181). Lima: Colección Arte y Tesoros del Perú, Banco de Crédito del Perú.

Castillo Butters, L. J. \& Quilter, J. (2010). Many Moche Models. An Overview of Past and Current Theories and Research on Moche Political Organization. In J. Quilter and L. J. Castillo B. (eds.), New Perspectives in the Political Organization of the Moche, (pp. 1-16). Washington, D.C.: Harvard University Press, Dumbarton Oaks Research Library and Collection.

Castillo Butters, L. J. \& Uceda, S. (2008). The Mochicas, in: H. Silverman and W. Isbell (eds.), Handbook of South American Archaeology (pp. 707-729). New York: Springer.

Castillo Butters, L. J. et alia (2012). The multidimensional relations between the Wari and the Moche states of Northern Peru Boletín de Arqueología PUCP, 16, 53-77. 
Chapdelaine, C. (200o). Struggling for Survival: The Urban Class of the Moche Site, North Coast of Peru. In G. Bawden \& R. M. Reycraft (eds.), Environmental Disaster and the Archaeology of Human Response (pp. 121-142). Albuquerque, New Mexico: Maxwell Museum of Anthropology.

Dillehay, T. (2001). Town and country in Late Moche times: A view from two northern valleys. In J. Pillsbury (ed.), Moche Art and Archaeology in Ancient Peru (pp. 259284). New Haven, CT: Center for Advanced Study in the Visual Arts Symposium Papers XL, National Gallery of Art, Yale University Press.

Distin, K. (2012). Symbolically Generalized Communication Media: A category Mistake? Constructivist Foundations 8 (1), 93-95.

Donnan, C \& McClelland, D. (1979). The Burial Theme in Moche Iconography. Studies on Pre-Columbian Art and Archaeological 21. Trustees for Harvard University. Washington D. C.: Dumbarton Oaks.

Donnan, C. (1973). The Thematic Approach to Moche Iconography Journal of Latin American Lore 12, 147-162.

Donnan, C. (2001). Moche ceramic portraits. In J. Pillsbury (ed.), Moche Art and Archaeology in Ancient Peru (pp. 127-140). New Haven, CT: Center for Advanced Study in the Visual Arts Symposium Papers XL, National Gallery of Art, Yale University Press.

Esposito, E. (2002). Soziales Vergessen. Formen und Medien des Gedächtnisses der Gesellschaft. Frankfurt am Main: Suhrkamp.

Esposito, E. (2007). Blinde Flecken der Medientheorie. In S. Dietz \& T. Skrandies (eds.), Mediale Markierungen. Studien zur Anatomie medienkultureller Praktiken (pp. 83100). Bielefeld: transcript Verlag.

Gagnon, C. M. (2008). Bioarchaeological investigations of pre-state life at Cerro Oreja. In L. J. Castillo Butters et alia (eds.), Arqueología Mochica. Nuevos enfoques (pp. 173-185). Lima: PUCP/IFEA.

Galarschelli, D. \& Loffredo, M. (2004). Patterns of link reciprocity in directed networks Phys. Rev. Lett. 93, 268701. https://doi.org/10.1103/PhysRevLett.93.268701

Gamboa, J. (2008). Plazas y cercaduras: Una aproximación a la arquitectura pública moche IV y V en los valles de Moche y Santa. In L. J. Castillo Butters et alia (eds.), Arqueología Mochica. Nuevos enfoques (pp. 203-217). Lima: PUCP/IFEA.

Giesecke, M. (2002). Von den Mythen der Buchkultur zu den Visionen der Informationsgesellschaft. Frankfurt am Main: Suhrkamp.

Golte, J. (1994). Iconos y narraciones. La reconstrucción de una secuencia de imágenes Moche. Lima: Instituto de Estudios Peruanos. 
Golte, J. (2009). Moche: cosmología y sociedad. Una interpretación iconográfica. Lima: Instituto de Estudios Peruanos.

Goody, J. (1997). Representantions and contradictions. Oxford: Blackwell Publishers.

Hill Boone, E. (200o). Stories in red and black. Pictorial histories of the Aztecs and Mixtecs. Austin: University of Texas Press.

Hill Boone, E. (2012). Discourse and authority in Histories painted, knotted, and threaded. Ethnohistory, 59:2, 211-237.

Hocquenghem, A. M. (2008). Sacrifices and ceremonial calendars in societies of the Central Andes. In S. Bourget \& K. Jones (ed.), The Art and Archaeology of the Moche (pp. 2342). Austin: University of Texas Press.

Hocquenghem, A.M. (1987). Iconografía mochica. Lima: Fondo Editorial de la Pontificia Universidad Católica del Perú.

Kaulicke, P. (1992). Moche, Vicús-Moche y el Mochica Temprano Boletín del Instituto Francés de Estudios Andinos 21(3), 853-903.

Kieserling, A. (1999). Kommunikation unter Anwesenden. Frankfurt am Main: Suhrkamp.

Koons, M. (2015). Moche sociopolitical dynamics and the role of Licapa II, Chicama Valley, Peru Latin American Antiquity 26(4), 473-492.

Kunzler, J. (1989). Medien und Gesellschaft. Die Medienkonzepte von Talcott Parsons, Jürgen Habermas und Niklas Luhmann. Stuttgart: Ferdinand Enke Verlag.

Larco Hoyle, R. (2001 [1938/1939]). Los Mochicas, Tomos 1 \& 2. Lima: Museo Arqueológico Rafael Larco Herrera.

Lockard, G. (2008). A new view of Galindo: Results of the Galindo archaeological project. In L. J. Castillo Butters et alia (eds.), Arqueología Mochica. Nuevos enfoques (pp. 275294). Lima: PUCP/IFEA.

Luhmann, N. (1979). Trust and power. Two works by Niklas Luhmann. New York: John Wiley \& Sons.

Luhmann, N. (1980). Frühneuzeitliche Anthropologie: Theorietechnische Lösungen für ein Evolutionsproblem der Gesellschaft. In N. Luhmann, Gesellschaftsstruktur und Semantik, Bd. 1, (pp.162-234). Frankfurt am Main: Suhrkamp.

Luhmann, N. (1981). Über die Funktion der Negation in sinnkonstituirenden Systemen. In N. Luhmann, Soziologische Aufklärung 3 (pp. 35-49). Opladen: Westdeutscher Verlag.

Luhmann, N. (1987). Rechtssoziologie. Opladen: Westdeutscher Verlag.

Luhmann, N. (1991). Evolution und Geschichte. In N. Luhmann, Soziologische Aufklärung 2 (pp. 150-169). Opladen: Westdeutscher Verlag.

Luhmann, N. (1991b). Systemtheorie, Evolutionstheorie und Kommunikationstheorie. In N. Luhmann, Soziologische Aufklärung 2 (pp. 193-203). Opladen: Westdeutscher Verlag. 
Luhmann, N. (1991c). Einführende Bemerkungen zu einer Theorie symbolisch generalisierten Kommunikationsmedien. In N. Luhmann, Soziologische Aufklärung 2 (pp. 170-192). Opladen: Westdeutscher Verlag.

Luhmann, N. (1992). Die Wissenschaft der Gesellschaft. Frankfurt am Main: Suhrkamp.

Luhmann, N. (1995). Social Systems. Stanford, Cal.: Stanford University Press.

Luhmann, N. (200o). Art as a social system. Stanford, Cal.: Stanford University Press.

Luhmann, N. (2002). How can the Mind Participate in Communication? In N. Luhmann, Theories of Distinction (pp. 169-186). Stanford, Cal.; Stanford University Press.

Luhmann, N. (2008). Die Ausdifferenzierung von Erkenntnisgewinn: Zur Genese von Wissenschaft. In N. Luhmann, Ideenevolution (pp. 132-185). Frankfurt am Main: Suhrkamp.

Luhmann, N. (2012). Theory of Society, Vol. 1. Stanford, Cal.: Stanford University Press.

Luhmann, N. (2017). Systemtheorie der Gesellschaft. Berlin: Suhrkamp.

Makowski, K. (1994). Los Señores de Loma Negra. In K. Makowski (ed.), Vicús (pp. 135-141). Lima: Colección Arte y Tesoros del Perú, Banco de Crédito del Perú.

Makowski, K. (2006). La arquitectura pública del periodo precerámico tardío y el reto conceptual del urbanismo andino Boletín de Arqueología PUCP 10, 167-199.

Mauss, M. (2009). Ensayo sobre el don. Buenos Aires: Katz Editores.

Moore, J. (1996). Architecture and Power in the Ancient Andes. The Archaeology of Public Buildings. Cambridge: Cambridge University Press.

Moseley, M. (2001). The Incas and their Ancestors, the Archaeology of Peru. New York: Thames and Hudson.

Netherly, P. (1990). Out of Many, One: The Organization of Rule in the North Coast Polities. In M. Moseley \& A. Cordy-Collins (eds.), The Northern Dynasties: Kingship and Statecraft in Chimor (pp. 461-487). Washington, D.C: Dumbarton Oaks.

Quilter, J. \& Koons, M. (2012). The fall of the Moche: A critique of claims for South America`s first state Latin American Antiquity 23 (2), 127-143.

Quilter, J. (1997). The Narrative Approach to Moche Iconography Latin American Antiquity $8(2), 113-33$.

Quilter, J. (2002). Moche Politics, Religion, and Warfare Journal of World Prehistory, 16 (2), 145-195. https://doi.org/o892-7537/o2/o6oo-0145/o

Ringberg, J. (2008). Figurines, household rituals, and the use of domestic space in a middle Moche rural community. In L. J. Castillo Butters et alia (ed.), Arqueología Mochica. Nuevos enfoques (pp. 341-357). Lima: PUCP/IFEA. 
Schiewek, W. (1992). Zum vernachlässigten Zusammenhang von >symbolischer Generalisierung $<$ und $>$ Sprache $<$ in der Theorie sozialer Systeme. In W. Krawietz \& M. Welker (Hrsg.), Kritik der Theorie sozialer Systeme (pp. 147-161). Frankfurt am Main: Suhrkamp.

Shimada, I. (1994). Pampa Grande and the Mochica Culture. Austin: University of Texas Press.

Shimada, I. et alia (2008). The Moche people. Genetic perspective on their sociopolitical composition and organization. In S. Bourget \& K. Jones (ed.), The Art and Archaeology of the Moche (pp. 179-193). Austin: University of Texas Press.

Swenson, E. \& Warner, J. (2012). Crucibles of Power: Forging copper and forging subjects at the Moche ceremonial center of Huaca Colorada, Peru Journal of Anthropological Archaeology 31, 314-333. http://doi.org/10.1016/j.jaa.2012.01.010

Swenson, E. (2006). Competitive Feasting, Religious Pluralism and Decentralized Power in the Late Moche Period. In W. Isbell \& H. Silverman (ed.), Andean Archaeology III. North and South (pp. 112-142). New York: Springer.

Swenson, E. (2011). Stagecraft and the Politics of Spectacle in Ancient Peru Cambridge Archaeological Journal 21 (2), 283-313. http://doi.org/10.1017/So95977431100028X

Swenson, E. (2012). Los fundamentos cosmológicos de las interacciones Moche-Sierra durante el horizonte medio en Jequetepeque. Boletín de Arqueología PUCP, 16, 79104.

Swenson, E. (2014). Dramas of the Dialectic: Sacrifice and Power in Ancient Polities. In R. Campbell (ed.), Violence and Civilization (pp. 28-6o). Oxford: Oxbow Books.

Topic, T. (1977). Excavations at Moche. Unpublished Ph.D. dissertation, Department of Anthropology. Cambridge: Harvard University.

Uceda S. \& Meneses, J. (2016). El urbanismo moche y el surgimiento del Estado y la ciudad en los Andes Centrales. In Actas del 1er Congreso Nacional de Arqueología Vol. 1 (pp. 9-18). Lima: Ministerio de Cultura.

Uceda, S. (2001). Investigations at Huaca de la Luna, Moche Valley: An example of Moche religious architecture. In J. Pillsbury (ed.), Moche Art and Archaeology in Ancient Peru (pp. 47-68). New Haven, CT: Center for Advanced Study in the Visual Arts Symposium Papers XL, National Gallery of Art, Yale University Press.

Urton, G. (2003). Signs of the Inka Khipu. Austin: University of Texas Press.

Verano, J. (1998). Sacrificios humanos, desmembramientos y modificaciones culturales en restos osteológicos: Evidencias de las temporadas de investigación 1995-1996 en Huaca de la Luna. In S. Uceda, E. Mujica \& R. Morales (ed.), Investigaciones en la Huaca de la Luna 1996 (pp. 159-171). Trujillo, Perú: Facultad de Ciencias Sociales, Universidad Nacional de Trujillo. 
White, H.C. (2008). Identity and Control: How Social Formations emerge. Princeton, N. J.: Princeton University Press. 